Article

\title{
Social Perception of Ecosystem Services in a Coastal Wetland Post-Earthquake: A Case Study in Chile
}

\author{
Octavio Rojas ${ }^{1, *}$ (D), María Zamorano ${ }^{1}$, Katia Saez ${ }^{2}$, Carolina Rojas ${ }^{3}$, Claudio Vega ${ }^{3}$, \\ Loretto Arriagada ${ }^{1}$ and Corina Basnou ${ }^{4}$ \\ 1 Department of Territorial Planning, Faculty of Environmental Sciences and EULA Chile Center, \\ Universidad de Concepcion, Concepción 4089100, Chile; mariaezamorano@udec.cl (M.Z.); \\ lorettoarriagada@gmail.com (L.A.) \\ 2 Department of Statistics, Faculty of Mathematical and Statistical Sciences, Universidad de Concepción, \\ Concepcion 4089100, Chile; ksaez@udec.cl \\ 3 Department of Geography, Faculty of Architecture, Urban Planning and Geography, \\ Universidad de Concepción, Concepción 4089100, Chile; crojasq@udec.cl (C.R.); clauvega@udec.cl (C.V.) \\ 4 Center for Ecological Research and Forestry Applications (CREAF), Universidad Autonoma de Barcelona, \\ Ballaterra 08193, Spain; c.basnou@creaf.uab.cat \\ * Correspondence: ocrojas@udec.cl; Tel.: +56-41-2207210
}

Received: 6 August 2017; Accepted: 26 October 2017; Published: 30 October 2017

\begin{abstract}
Natural disasters can cause abrupt disturbances in coastal wetlands, affecting the social perception of ecosystem services (ES). The Tubul-Raqui coastal wetland is one of the most important wetlands in south-central Chile. Rich in biodiversity, these wetlands provide ES to a population of 2238 inhabitants. The recent $M_{W}=8.8$ earthquake of 2010 caused a coastal uplift of $1.4 \mathrm{~m}$ and substantial morphological, social, and environmental changes. This paper analyzes the social perceptions of the inhabitants of the village of Tubul-Raqui following a large earthquake disturbance with regards to ES provision frequency and their future changes. A statistically representative semi-structured survey was conducted (175 valid surveys) and the data interpreted through factor analysis and statistical tests for independent categorical variables. The perception of cultural and regulating services was significantly greater than that of provisioning services, which were probably the most affected by the earthquake. Residents identified habitat for species, recreation, and hazard regulation as the most important ES. Perception was influenced by the categorical variables of gender, age, and ethnicity; for example, hazard regulation services varied strongly by gender. According to the respondents, the availability of ES will remain stable (50\%) or decrease $(40 \%)$ in the next 50 years, mainly due to anthropogenic drivers; the effect of natural disasters was not mentioned among the main drivers of change.
\end{abstract}

Keywords: ecosystem services; social perception; earthquake; abrupt disturbances; wetland; Chile

\section{Introduction}

Ecosystem services (ES) are defined as benefits that people obtain directly or indirectly from ecosystems, which are usually classified as provisioning, regulating, or cultural [1-4]. In this sense, wetlands provide a wide range of ES that contribute to human well-being [5-8], including algae and fish, ornamental species, natural disaster mitigation, microclimate regulation, aesthetic value, and tourism, among many others $[1,9,10]$. Thus, it is important to ensure the ecological integrity of these ecosystems to guarantee the continuity of their provision of ES. However, on a global scale, many studies agree that their loss and degradation are greater than those of other ecosystems, and are more severe in freshwater and coastal wetlands, particularly in the Mediterranean region [3,11,12]. In coastal wetlands, drivers of change are associated with direct (land-use cover changes, diversion of freshwater 
flows, changes in water temperature, and species invasions) and indirect factors (human population growth and increasing economic activity) [1,3]. However, some natural disasters (e.g., earthquakes, tsunamis, volcanic eruptions, storms) can cause abrupt disturbances in these ecosystems [13-16], therefore altering their ES provision.

This paper focuses on the social perception of ecosystem services in a coastal wetland in Chile, which were disturbed by a major earthquake. Salt marshes are a type of wetland that are especially sensitive to such disturbances. The ecosystem function of salt marshes depends on the interaction of fresh and salt water, which occurs in estuarine channels $[17,18]$. Large earthquakes can have an appreciable impact on the morphology and evolution of tectonically active coastal areas [17]. Depending on the coseismic tectonic dynamics of the affected area, the coast may undergo subsidence and/or uplift $[19,20]$; in the latter case, the tidal inflow into the estuary is diminished due to the close relationship between the altitude of the wetland and the local sea level [17]. For example, the relationship between ecosystem status and earthquakes was observed in the Sumatra-Andaman earthquake $\left(M_{\mathrm{W}}=9.1\right)$, where the coseismic uplift $(0.3-1.5 \mathrm{~m})$ caused plant mortality in large areas of coastal mangroves mainly due to thermal shock, desiccation, and the gradual depletion of soil salinity [21]. Earthquakes and tsunami disturbances have been associated with severe impacts on local human communities, due to the devastation of their crucial subsistence resources, as reported historically in the southern northwestern coast of the United States [13].

The above-mentioned cases demonstrate the complex links between the natural and social systems associated with human well-being [1,4,14]; therefore, it is important to incorporate social perceptions, historical drivers of change, trends, and social values in the evaluation of ES to guide criteria for sound environmental management strategies [3,22], an approach that is gaining prominence in the ES research agenda [23]. The social approach focuses on the values that society attributes to each ES [24] and considers that all individuals establish judgments and values regarding ecosystems and landscapes [25], which implies a diversity of individual values, interests and lifestyles, and thus an appreciation that depends on each context $[7,26,27]$.

The perceptions and preferences of the population regarding ecosystem services are influenced by a series of personal, geographic, and social characteristics such as age, gender, income, political orientations, environmental organizations, moral convictions, use and non-use of particular areas, life experiences, and living environment [4,22,23]. Maestre-Andrés et al. [28] identified education, age, and place of residence as the characteristics that most affected the sociocultural valuation of ES in a nature park (Spain). Other studies have identified ES provision based on the perceptions of the local people $[2,3,7,22,28,29]$; however, few have focused on the time after the occurrence of a major disaster (see Reference [14]), which is a priority in developing countries, where it has been estimated that the effects of the loss of ecosystem services on human well-being will be serious due to the low incomes and land-based personal economies of the affected populations [5]. Therefore, in areas prone to natural disasters, the analysis of current perceptions of ES and the understanding of their trends and drivers of change are of increased importance to maintain biodiversity, ecosystem functions, and assure population well-being.

Located in South America, Chile is a developing country that is highly exposed to natural disasters. The central region of Chile has a history of destructive earthquakes (1575, 1580, 1647, 1730, $1822,1906,1985[30,31])$ with the most recent event being the $2010 M_{\mathrm{W}}=8.8$ earthquake, that devastated south-central Chile [31]. The $2010 M_{\mathrm{W}}=8.8$ earthquake caused substantial morphological, social, and environmental changes in the coastal area of central Chile [15,32-37]. One of the most affected sectors was the Tubul-Raqui fishing village, located south of the Concepcion metropolitan area (thereafter CMA). Here, the Tubul-Raqui salt marsh offers ES provision mainly to a rural population with a high poverty rate [34,37]. In this area, the 2010 earthquake generated a coseismic coastal uplift estimated at $1.62 \pm 0.22 \mathrm{~m}$ (see Reference [20]), these dynamics have previously been observed in other events such as the great earthquake of 1835 [31,38]. The coastal uplift interrupted the entrance of the tide and partially dried the salt marsh, and generated a variation in the availability of ES provision, 
associated mainly with the extraction of the alga Gracilaria sp. (or pelillo in Spanish), which is important for the maintenance of the local economy $[37,39,40]$. In this context, we analyzed the social perception of the inhabitants of the village of Tubul-Raqui on the coast of central Chile to assess ES provision after the occurrence of a large earthquake. The data and methods applied can be replicated in areas of high ecological value affected by major disasters to understand the importance of ES after a great disturbance, therefore allowing an understanding of the implicit sociocultural differences based on each context.

\section{Materials and Methods}

\subsection{Study Area}

The Tubul-Raqui wetland (2238 ha) is a coastal salt marsh located on the Arauco Gulf, south of the $\mathrm{CMA}\left(37^{\circ} \mathrm{S}, 73^{\circ} \mathrm{W}\right)$ (Figure 1). Due to its extension and high biological biodiversity, it is one of the most important wetlands in south-central Chile $[37,39,41]$. Its ecosystem functions depend on the interaction and gradients of salt and fresh water. The intrusion of brackish water into the syzygy extended 5-6 km upstream from the mouths of the Tubul and Raqui rivers [39,42,43]. These natural dynamics generate optimum conditions for the cultivation of the alga Gracilaria sp., or pelillo [37,39]. The exploitation of pelillo, combined with the extraction of marine mollusks and fish, generated income linked to the food supply. In addition, the water supplied by the wetland allowed the development of small-scale agricultural and livestock activity, which is limited by the poor quality of soils in the area [37,39]; furthermore, these economic activities are undertaken by a vulnerable population $[34,37]$.

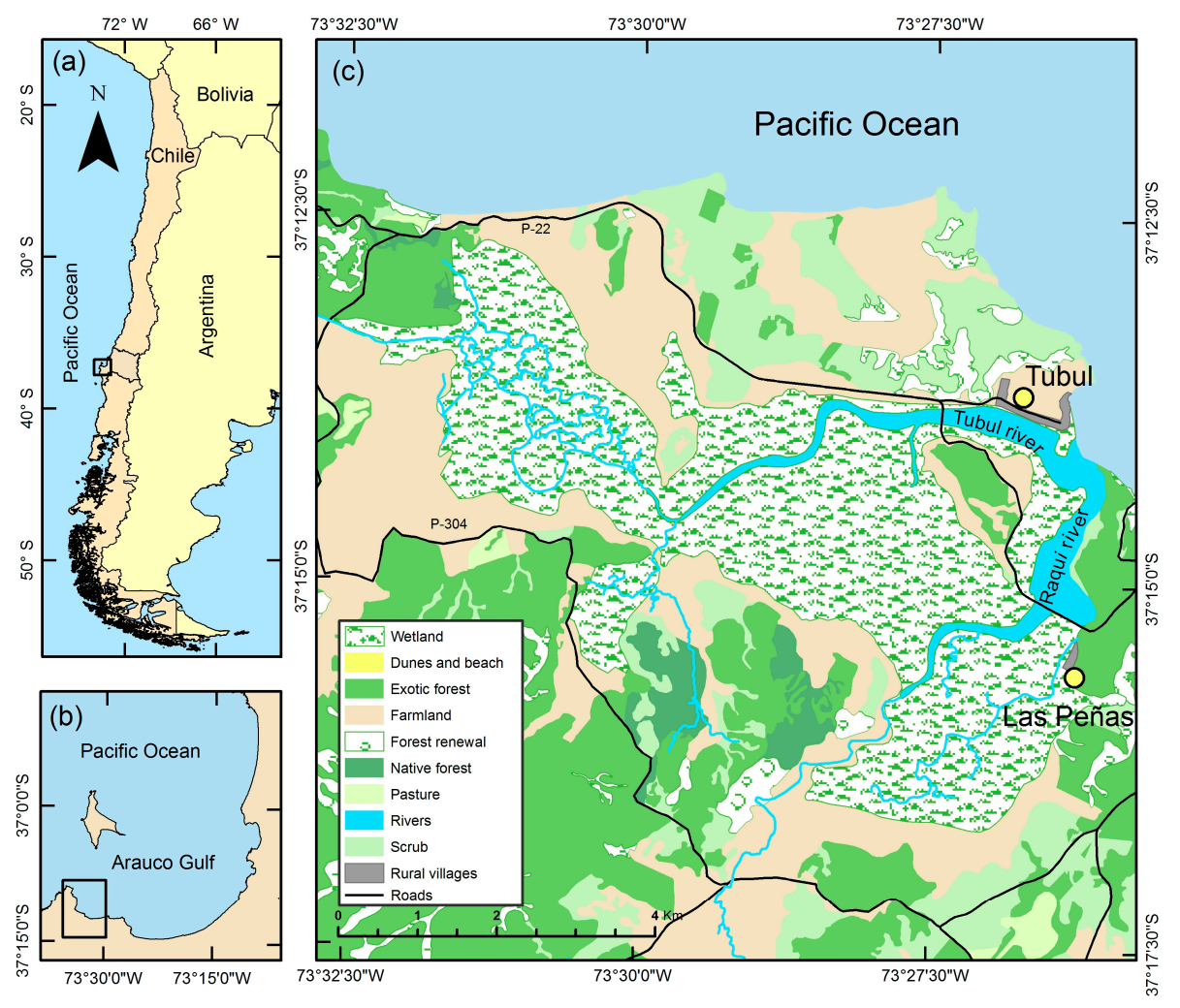

Figure 1. Study area. $(\mathbf{a}, \mathbf{b})$ indicate the geographical contexts in the South America region; (c) Location of the wetland and land use cover in the Tubul-Raqui basin.

The estimated human population is about 2683 , which is concentrated in the rural villages of Tubul $(75 \%)$ and Las Peñas $(12 \%)$ [37,39]. In addition, official statistics from the government of Chile [44] report that about 200 people in Tubul belong to indigenous ethnic groups. Their main economic 
activities focus on fishing, agriculture, and livestock, where the latter two are carried out on a family scale mostly for local supply [37]. Fishing comprises of artisanal fishing and the extraction of the alga Gracilaria sp., which was carried out by about 500 people before the earthquake of 2010 [39]. The population has a low income, even lower than the legal minimum wage established in Chile [37].

\subsection{Methodology}

Data collection to analyze the social perception or perceived benefits of ecosystem services was carried out by conducting a semi-structured survey. The process was divided into three consecutive steps: (1) survey design; (2) determination of population and sample size; and (3) data analysis.

\subsubsection{Survey Design}

The instrument was designed with three main sections: (a) personal background of the head of the household; (b) socioeconomic data; and (c) their perception of ecosystem services. For background information on the head of the household, subjects were asked about gender, age, years of schooling, and indigenous group membership. The socioeconomic information comprised household members, economic activity, individuals with incomes, the incomes of household members, and government subsidies. Income information was detailed to obtain better reliability in income declarations, as proposed by Paul [45] and Rojas et al. [37].

To construct the section on the perception of ecosystem services, an initial stage consisted of a literature review of the services and subservices provided by wetlands including the Millennium Ecosystem Assessment, among other works described in References [1,12], which were then used to establish a final base of 64 subservices. An assessment of the services provided by the Tubul-Raqui wetland was carried out and 64 possible services were rated by a commission of ten experts from different fields of sociology, environmental sciences, biology, forestry engineering and geography, who determined the relative magnitude (high, medium, low) of the ecosystem services of the studied system. Finally, a list of 30 services (Table 1) were obtained for assessment, which consisted of provisioning, regulating, and cultural services.

Table 1. Ecosystem services provision analyzed.

\begin{tabular}{lll}
\hline \multicolumn{1}{c}{ Provisioning ES } & \multicolumn{1}{c}{ Regulating ES } & \multicolumn{1}{c}{ Cultural ES } \\
\hline Livestock development & Control of soil erosion & Appreciation of fauna \\
\hline Food cultivation & $\begin{array}{l}\text { Hydrological hazard protection } \\
\text { (tsunamis, floods) }\end{array}$ & Appreciation of flora \\
\hline Fodder for cattle & Fire protection & Mental recreation (relaxation, stress reduction) \\
\hline Wild fruit collection & Microclimate regulation & Maintenance of social relations \\
\hline Water for domestic use & Discharge regulation & Aesthetic value \\
\hline Fuelwood collection & Water purification & Maintenance of traditional knowledge \\
\hline Water for agricultural use & Air purification & Opportunities for sports \\
\hline Ornamental resource collection & Habitat for species & Opportunities for eco-tourism \\
\hline Medicinal plant collection & Pollination & Opportunities for scientific activity \\
\hline Fish and algae production & Groundwater recharge & Opportunities for environmental education \\
\hline
\end{tabular}

\subsubsection{Determination of Population and Sample Size}

To calculate a sample that determined the social perception of the ecosystem services in the Tubul-Raqui coastal wetland, we used the methodological parameters of Rojas et al. [37]. The population $(\mathrm{N})$ was defined as the heads of households older than 18 years, either female or 
male, who resided in the Tubul-Raqui area; through a housing census, 280 households were obtained. The sample size $(n)$ was calculated using the formula for finite populations (Equation (1)):

$$
n \geq \frac{\mathrm{N} z^{2}{ }_{1-\mathrm{a} / 2} \mathrm{PQ}}{z^{2}{ }_{1-\mathrm{a} / 2} \mathrm{PQ}+d^{2}(\mathrm{~N}-1)}
$$

where $n$ corresponds to sample size; $\mathrm{N}$ is the population size (280); $\mathrm{Z}$ is the normal distribution value (95\%); $\mathrm{P}$ is the estimated population proportion (70\%); $d$ is the precision (5\%); and $Q$ the proportion of unfavorable results in the population $(q=1-p)$. In this study, the population proportion was estimated based on the percentage of people working in the different economic sectors.

The application of the formula for finite populations fixed 160 heads of households as $n$ (sample size). For reasons of loss or rejection, it was necessary to apply $10 \%$ more surveys than the calculated sample size. Finally, 175 valid surveys were obtained. Five interviewers were trained to apply the instrument. The house-to-house survey was randomly conducted during four days of fieldwork, and the time associated with each questionnaire was approximately $25 \mathrm{~min}$. Table 3 shows general information regarding the survey respondents.

\subsubsection{Data Analysis}

The data were analyzed using IBM SPSS (Statistical Package for the Social Sciences) version 24.0 [46] and InfoStat version 2015p [47]. The general information regarding the survey respondents was categorized (Table 2). Age was categorized according to the stages of development proposed by Martín [48], who considered young adults (18-35 years), intermediate adults (36-49 years), mature adults (50-64 years), and seniors ( $\geq 65$ years). Work activities were classified based on the recommendations of the National Institute of Statistics of Chile, by primary (e.g., agriculture, livestock), secondary (e.g., industry), and tertiary (e.g., commerce) economic sectors. For education, years of study grouped into three levels were considered: basic ( $0-4$ years), advanced basic (5-8 years), and secondary (9-12 years). To identify conditions of poverty, the national economic characterization survey [49] model was applied, which determines poverty according to the number of household members and their per capita income.

Table 2. General information regarding survey respondents.

\begin{tabular}{cccc}
\hline Category & Category & Frequency (Person) & Ratio (\%) \\
\hline \multirow{2}{*}{ Gender } & Male & 37 & 79.0 \\
& Female & 138 & 21.0 \\
\hline \multirow{2}{*}{ Age } & $18-35$ & 32 & 18.3 \\
& $36-49$ & 54 & 30.9 \\
& $50-64$ & 59 & 33.7 \\
\multirow{2}{*}{ Economic sector } & $\geq 65$ & 30 & 17.1 \\
& Primary sector & 139 & 79.4 \\
& Secondary sector & 5 & 2.9 \\
& Tertiary sector & 18 & 10.3 \\
\multirow{2}{*}{ Education (years) } & Retirees and pensioners & 13 & 7.4 \\
& $0-4$ & 40 & 22.9 \\
& $5-8$ & 84 & 48.0 \\
\hline \multirow{2}{*}{ Poverty situation } & $9-12$ & 51 & 29.1 \\
\hline \multirow{2}{*}{ Ethnicity } & Poverty & 129 & 73.7 \\
& No poverty & 46 & 26.3 \\
\hline Total (n) & Indigenous & 23 & 13.1 \\
& Non-indigenous & 152 & 86.9 \\
\hline
\end{tabular}


The reliability of the obtained perception results on a Likert scale (Table 3) was determined using Cronbach's alpha coefficient, which was generally applied for all ecosystem services and for particular service categories. The minimum value for accepting the test was 0.70 [50], and the analyses gave coefficients above 0.70 in all areas with an overall value of 0.83 (Table 4), indicating high instrument reliability. Construct validity was obtained through factor analysis. To analyze the data, a factor analysis was applied, which allowed groups of variables (components) with common characteristics to be identified to explain the greatest possible amount of information.

To determine the relationship between the components of the three dimensions and the independent categorical variables (gender, age, education, poverty, ethnicity, and economic sector), the Student's $t$-test (Mann-Whitney U.) was applied in the case of two groups and the analysis of variance (Kruskal-Wallis) in the case of more than two groups. For age, the Pearson correlation coefficient was obtained. When a sub-dimension was composed of only one question, the chi-squared test was applied. Three levels of significance was used $(0.10,0.05$ and 0.01$)$.

Table 3. Likert scale example applied to determine the current perception of ecosystem services.

\begin{tabular}{cccccc}
\hline Ecosystem Services & Never & Very Rarely & Occasionally & Very Frequently & Always \\
\hline Fodder for cattle & 1 & 2 & 3 & 4 & 5 \\
Wild fruit collection & 1 & 2 & 3 & 4 & 5 \\
\hline
\end{tabular}

Table 4. Cronbach's alpha reliability coefficients by dimension.

\begin{tabular}{ccc}
\hline Dimension & Number of Elements & Cronbach's Alpha \\
\hline Provisioning services & 10 & 0.72 \\
Regulating services & 10 & 0.76 \\
Cultural services & 10 & 0.78 \\
Total & 30 & 0.83 \\
\hline
\end{tabular}

To calculate the perception of change trend for the different ecosystem services, the overall perceived trend index proposed by Oteros-Rozas et al. [29] was used. The index is defined by (Equation (2)):

$$
\text { Overall perceived trend }=\left[\frac{I-D}{I+D+M}\right]
$$

where $I$ is the frequency of increases; $D$ is the frequency of decreases; and $M$ corresponds to the frequency of stability. The results were interpreted as: $1.00-0.60$ were mostly increases; $0.59-0.29$ were increases; $0.19--0.19$ was stable; $-20--0.59$ were decreases; and $-0.60--1.00$ were mostly decreases.

\section{Results}

\subsection{Current Perception}

The perceived benefits of the ecosystem services of the Tubul-Raqui wetland according to the Likert scale categories is summarized in Figure 2. It was observed that the results were concentrated at the extremes of the scale (never, very rarely, very frequently, and always). Regarding provisioning services, there was a mostly negative perception with $66 \%$ of respondents indicating that they rarely or never used them. Regulating or cultural services were better evaluated, with approximately $56 \%$ and $55 \%$ of inhabitants, respectively, of the fishing village indicating that they frequently or always used them. 


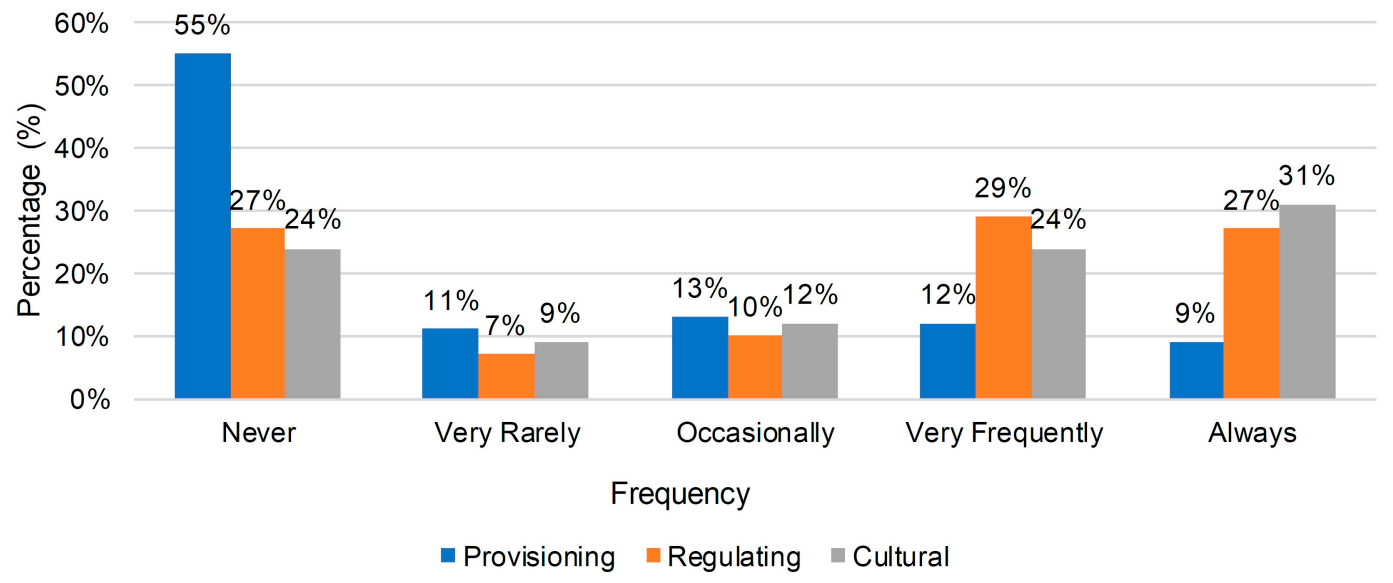

Figure 2. Likert results regarding the current perception of ecosystem services.

The internal relationship among the various services that made up each category was determined through factor analysis, which successfully grouped ecosystem services by dimension as per the Kaiser-Meyer-Olkin test $(\mathrm{KMO}=0.716)$. The provisioning services dimension was made up of four components (Table 5) that explained $66.7 \%$ of the total variance. The first component, referred to as livestock and crop development explained $30.7 \%$ of the variance, and the ecosystem services grouped in this component were livestock development, food cultivation, fodder for cattle, and wild fruit collection. The second component, related to the provision of water and fuelwood, explained $14.1 \%$ of the variance. The third and fourth components explained $11 \%$ of the variance, on average, respectively; the third was related to the collection of plants for ornamental and medicinal purposes and the final component to the fish and algae production.

Table 5. Rotated component matrix one and total variance explained for dimension one (provisioning).

\begin{tabular}{ccccc}
\hline \multirow{2}{*}{ Provision Ecosystem Services } & \multicolumn{4}{c}{ Component } \\
\cline { 2 - 5 } & $\mathbf{1}$ & $\mathbf{2}$ & $\mathbf{3}$ & $\mathbf{4}$ \\
\hline Livestock development & 0.811 & & \\
Food cultivation & 0.727 & & & \\
Fodder for cattle & 0.614 & & & \\
Wild fruit collection & 0.528 & & & \\
Water for domestic use & & 0.870 & & \\
$\quad$ Fuelwood collection & & 0.810 & & \\
Water for agricultural use & & 0.676 & & \\
Ornamental resource collection & & & & \\
Medicinal plant collection & & & 11.1 & 10.8 \\
Fish and algae production & & & 55.9 & 66.7 \\
\hline \% Variance & 30.7 & 14.1 & \\
\hline \% Cumulative variance & 30.7 & 44.8 & & \\
\hline
\end{tabular}

The second dimension, the regulating ecosystem services, was formed by three components that explained $69.7 \%$ of the total variance (Table 6). The first component related mainly to hazard regulation (29.1\% of the variance), with soil erosion control, hydrological hazard protection and fire protection grouped in this component. The second component, made up of discharge and microclimate regulation, accounted for $21.1 \%$ of the common variance of the data. The last component was composed of the water and air purification services, and explained $19.5 \%$ of the variance. The ecosystem services of habitat for species, pollination, and groundwater recharge were not related to any component; therefore, their analysis by categorical variables was performed independently. 
Table 6. Rotated component matrix and total variance explained for dimension two (regulating).

\begin{tabular}{cccc}
\hline Regulating Ecosystem Services & \multicolumn{3}{c}{ Component } \\
\cline { 2 - 4 } & $\mathbf{1}$ & $\mathbf{2}$ & $\mathbf{3}$ \\
\hline Control of soil erosion & 0.786 & & \\
Hydrological hazard protection (tsunamis, floods) & 0.766 & & \\
$\quad$ Fire protection & 0.704 & & \\
Microclimate regulation & & 0.866 & \\
Discharge regulation & & 0.628 & 0.757 \\
Water purification & & & 0.658 \\
$\quad$ Air purification & & & 19.5 \\
\% Variance & 29.1 & 21.1 & 69.7 \\
\hline Cumulative variance & 29.1 & 50.2 &
\end{tabular}

For cultural services, three components explained $74.2 \%$ of the total variance (Table 7$)$. The first component was interpreted as landscape recreation related to the appreciation of natural attributes and mental recreation, and explained $22.9 \%$ of the variance. The second component, local identity, explained $18.7 \%$ of the variance, and was mainly associated with aspects of social relationships, local traditions, and a sense of place. The third component was linked to the development of tourism and eco-tourism, and explained $16.6 \%$ of the variance. Finally, the fourth component of scientific activity and environmental education accounted for $16.0 \%$ of the variance.

Table 7. Rotated component matrix and total variance explained for dimension three (cultural).

\begin{tabular}{ccccc}
\hline Cultural Ecosystem Services & \multicolumn{5}{c}{ Component } \\
\cline { 2 - 6 } & $\mathbf{1}$ & $\mathbf{2}$ & $\mathbf{3}$ & $\mathbf{4}$ \\
\hline Appreciation of fauna & 0.862 & & & \\
Appreciation of flora & 0.845 & & & \\
Mental recreation (relaxation, stress reduction) & 0.620 & & & \\
Maintenance of social relations. & & 0.877 & & \\
Aesthetic value & & 0.695 & & \\
Maintenance of traditional knowledge & & 0.641 & & \\
Opportunities for sports & & & 0.891 & \\
Opportunities for eco-tourism & & & 0.847 & \\
Opportunities for scientific activity & & & & 0.858 \\
Opportunities for environmental education & & & & 0.828 \\
\hline \% Variance & 22.9 & 18.7 & 16.6 & 16.0 \\
\% Cumulative variance & 22.9 & 41.6 & 58.2 & 74.2 \\
\hline
\end{tabular}

Figure 3 shows the average valuation and the standard error obtained for components associated with each dimension of the factor analysis. It was observed that the regulating and cultural services presented a higher valuation than the provisioning category. Regulating services were well perceived by the inhabitants of the fishing village, with habitat for species (4.1), hazard regulation (3.7), and microclimate and discharge regulation (3.0) standing out; water and air purification was also perceived to be on the same level of importance. Cultural services were also important, among which the possibility of recreation given the attributes of the landscape was the highest valued (3.9), followed by local identity (3.6), and the development of science and environmental education (3.2); however, opportunities for tourism and sports obtained the lowest value (2.5) in this category. In provisioning services, the development of livestock and crops (2.0) along with water and fuelwood (1.7) obtained the lowest weights, most likely due to the environmental conditions (e.g., brackish water and poor soil) of the salt marsh. In this final category, the positive assessment associated with plant extraction (2.4), and fish and algae production (2.6) stood out. 


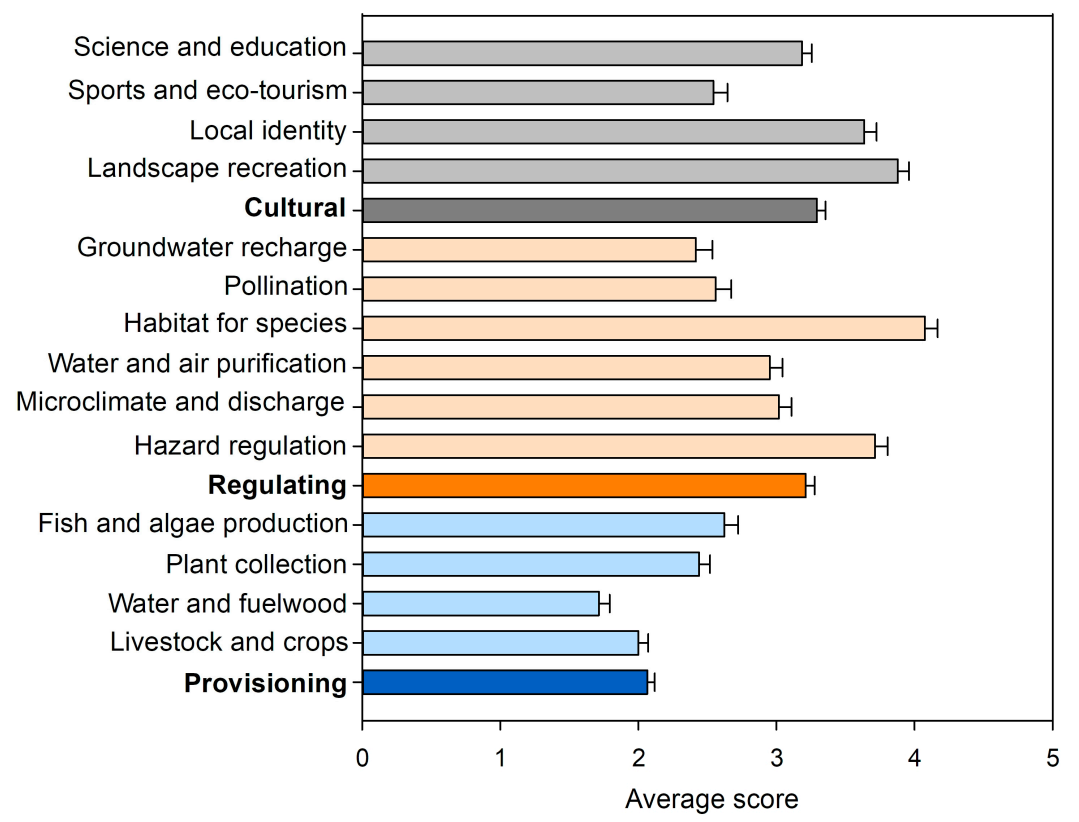

Figure 3. Average score and standard error for each evaluated component or ecosystem service.

This last positive assessment regarding fish and algae may be linked to the boom in the production of the alga Gracilaria sp. in the area. Indeed, in the data (corresponding to landings in tons) presented in Figure 4 showed that constant growth in activity was observed until 2010, with a peak in activity in the 2005-2010 period. The year 2010 marked a break in extraction; although levels similar to those in previous years were observed, these data corresponded to the months of January and February during which extraction reached 5436 tons. Following the earthquake and tsunami of 2010, there was a total loss of the resource, with large meadows completely exposed to an environment without salt water. Starting in 2013, a gradual recovery of the activity was observed, but was still at very low levels in comparison to pre-disturbance extraction levels.

The analysis of the assessment by independent categorical variables showed greater significant differences for gender, age, and ethnicity, while lower levels of significance were obtained for the education and economic sectors (Table 8 ). Regarding gender, women gave a higher valuation to hazard regulation $(p=0.002)$, water and fuelwood $(p=0.026)$, water and air purification $(p=0.032)$, and groundwater recharge $(p=0.027)$ services; in addition, slightly significant differences in microclimate and discharge $(p=0.099)$ and local identity $(p=0.070)$ were found. With respect to the age variable, a negative correlation in plant extraction $(p=0.033)$, livestock and crops $(p=0.078)$, and fish and algae $(p=0.040)$ services was obtained, with the highest valuation given by young and intermediate adults (18-49 years). In contrast, in the microclimate and discharge $(p=0.050)$ and habitat for species $(p=0.007)$ services, a positive correlation regarding mature adults and seniors (over 50 years) was reported. 


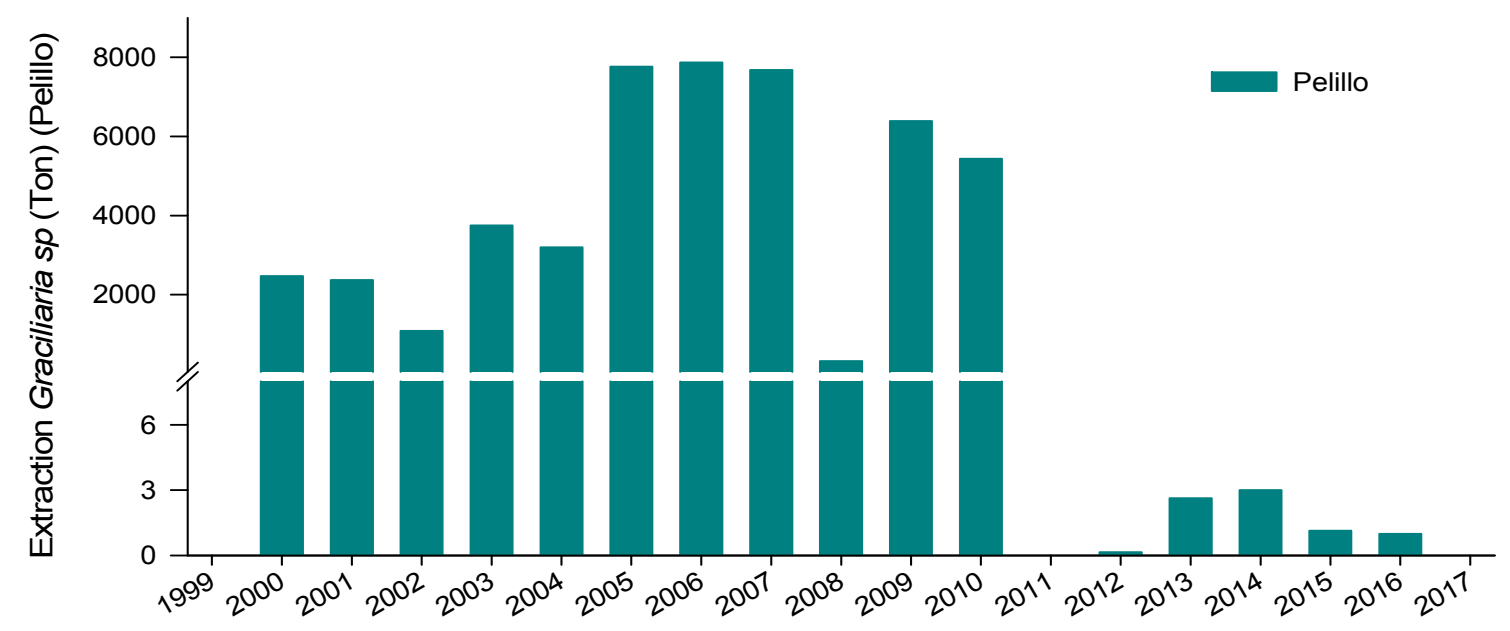

Figure 4. Gracilaria sp. extraction 2000-2017, Tubul-Raqui village (tons).

Ethnicity exhibited greater valuations in indigenous groups in five ecosystem services, with significant differences obtained in fish and algae production $(p=0.049)$, groundwater recharge $(p=0.013)$, opportunities for sports and eco-tourism $(p=0.031)$, and science and education $(p=0.002)$, along with a slightly significant difference in water and fuelwood provision $(p=0.074)$. With respect to the economic sector, there was a slight significant difference in only one service, fish and alga extraction $(p=0.073)$, which was valued to a greater degree by those who did not belong to the primary economic sector. Regarding the poverty variable, there were no significant differences.

Table 8. Component significance for independent categorical variables.

\begin{tabular}{ccccccc}
\hline Component or ES & Gender & Age & Education & Ethnicity & Poverty & Economic Sector \\
\hline Provisioning & $0.061^{+}$ & $0.021^{*}$ & 0.794 & 0.318 & 0.366 & 0.924 \\
Livestock and crops & 0.300 & $0.078^{+}$ & 0.602 & 0.309 & 0.509 & 0.871 \\
Water and fuelwood & $0.026^{*}$ & 0.427 & $0.033^{*}$ & $0.074^{+}$ & 0.389 & 0.438 \\
Plant collection & 0.633 & $0.033^{*}$ & 0.379 & 0.268 & 0.776 & 0.299 \\
Fish and algae production & 0.981 & $0.040^{*}$ & 0.717 & $0.049^{*}$ & 0.331 & $0.073^{+}$ \\
Regulating & $0.002^{* *}$ & 0.271 & 0.259 & 0.217 & 0.741 & 0.274 \\
Hazard regulation & $0.002^{* *}$ & 0.133 & 0.226 & 0.771 & 0.829 & 0.675 \\
Microclimate and discharge & $0.099^{+}$ & $0.050^{*}$ & 0.426 & 0.351 & 0.423 & 0.805 \\
Water and air purification & $0.032^{*}$ & 0.516 & 0.713 & 0.511 & 0.278 & 0.159 \\
Habitat for species & 0.247 & $0.007^{* *}$ & 0.923 & 0.487 & 0.432 & 0.366 \\
Pollination & 0.651 & 0.793 & $0.001^{* *}$ & 0.264 & 0.618 & 0.694 \\
Groundwater recharge & $0.027^{*}$ & 0.171 & 0.798 & $0.013^{*}$ & 0.489 & 0.902 \\
Cultural & 0.199 & 0.372 & 0.614 & $0.067^{+}$ & 0.727 & 0.612 \\
Landscape recreation & 0.122 & 0.163 & 0.885 & 0.765 & 0.504 & 0.600 \\
Local identity & $0.070^{+}$ & 0.636 & 0.647 & 0.279 & 0.601 & 0.572 \\
Sports and eco-tourism & 0.883 & 0.770 & 0.331 & $0.031^{*}$ & 0.847 & 0.895 \\
Science and education & 0.637 & 0.256 & 0.292 & $0.002^{* *}$ & 0.410 & 0.131 \\
\hline
\end{tabular}

Significance levels: ${ }^{* *} p<0.01 ;{ }^{*} p<0.05 ;{ }^{+} p<0.10$.

\subsection{Perception of Future Change}

The perception of future ecosystem service change trends index over 50 years showed that $50 \%$ of the ES provision should remain stable, along with a 33.3\% decrease, and a $6.7 \%$ of mostly decrease (Figure 5). The perception of growth was low among the respondents, with only $6.7 \%$ and $3.3 \%$ holding that the services would increase or mostly increase, respectively. The analysis by service dimension - the greatest perception of future change-was obtained in cultural services, which should increase or remain stable in the coming years. Indeed, this category contained the only assessed services that would increase, such as opportunities for eco-tourism, sports, and scientific research. The population estimated that the services associated with regulating and provisioning would decrease 
and mostly decrease by $60 \%$; in the slight decrease category, air purification, microclimate regulation, and water for domestic and agricultural use ES, among others, stood out. The service that would decrease most was the provision of fish and algae, with $85 \%$ of the population estimating that it would undergo a significant decrease.

Perception regarding increases, stability, or decreases in ES provision was found to be linked to drivers of disturbance and loss. Through an open question, we detected 11 drivers of change that would produce a decrease in the availability of ES. As observed in Figure 6, for the category of gender, no significant differences with other independent categorical variables were reported ( $p \geq 0.05)$. The main drivers were contamination (54.3\%), droughts (32.6\%), forestry industry presence $(28 \%)$, global climate change (22.9\%), human interventions associated with energy projects $(20.6 \%)$, and lack of environmental education (19.4\%). Percentages lower than $10 \%$ were obtained for overexploitation, absence of protection laws, natural disasters, religion, and natural degradation.

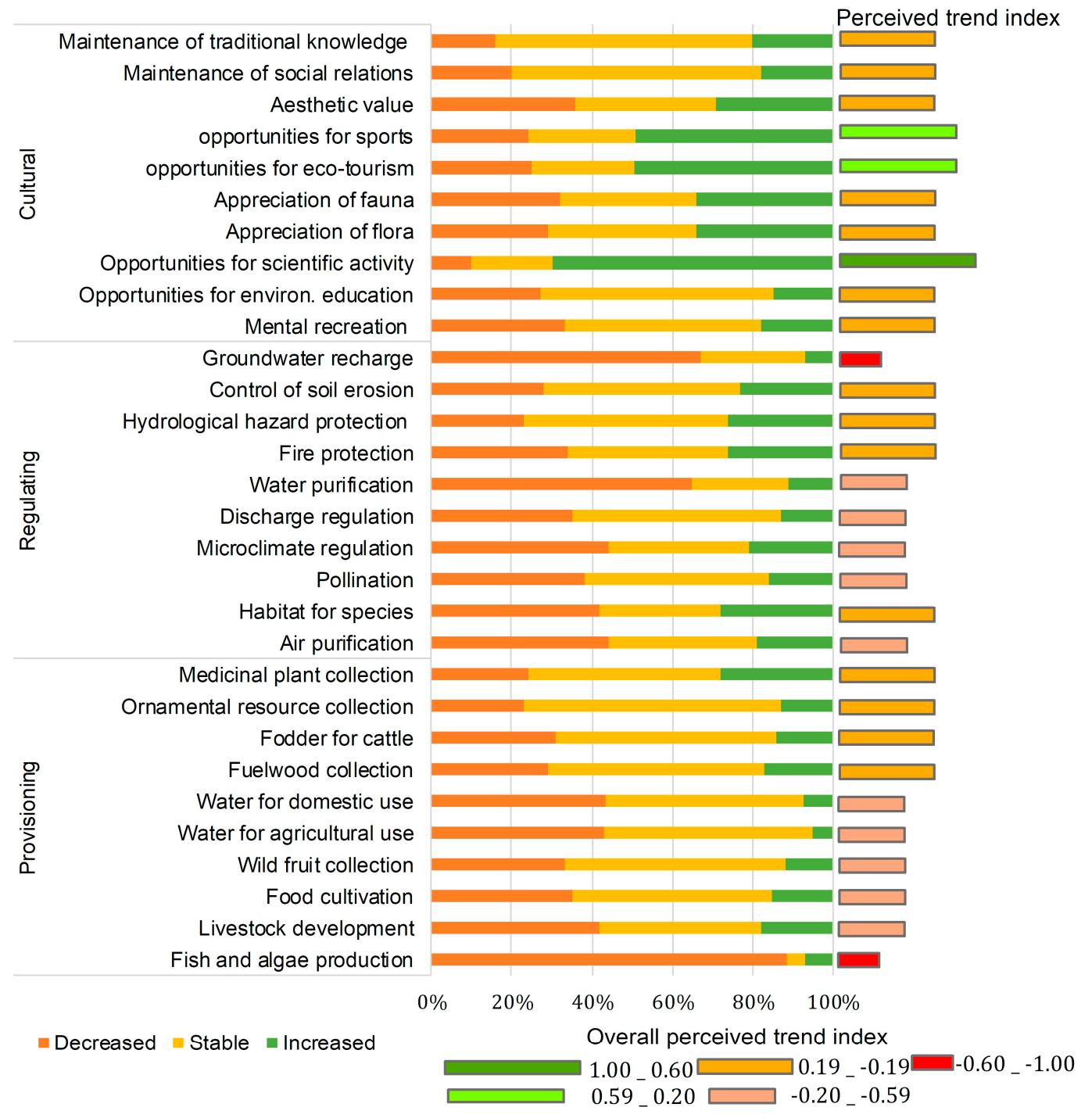

Figure 5. Perception of future change in ecosystem services and index of overall perceived trend. 


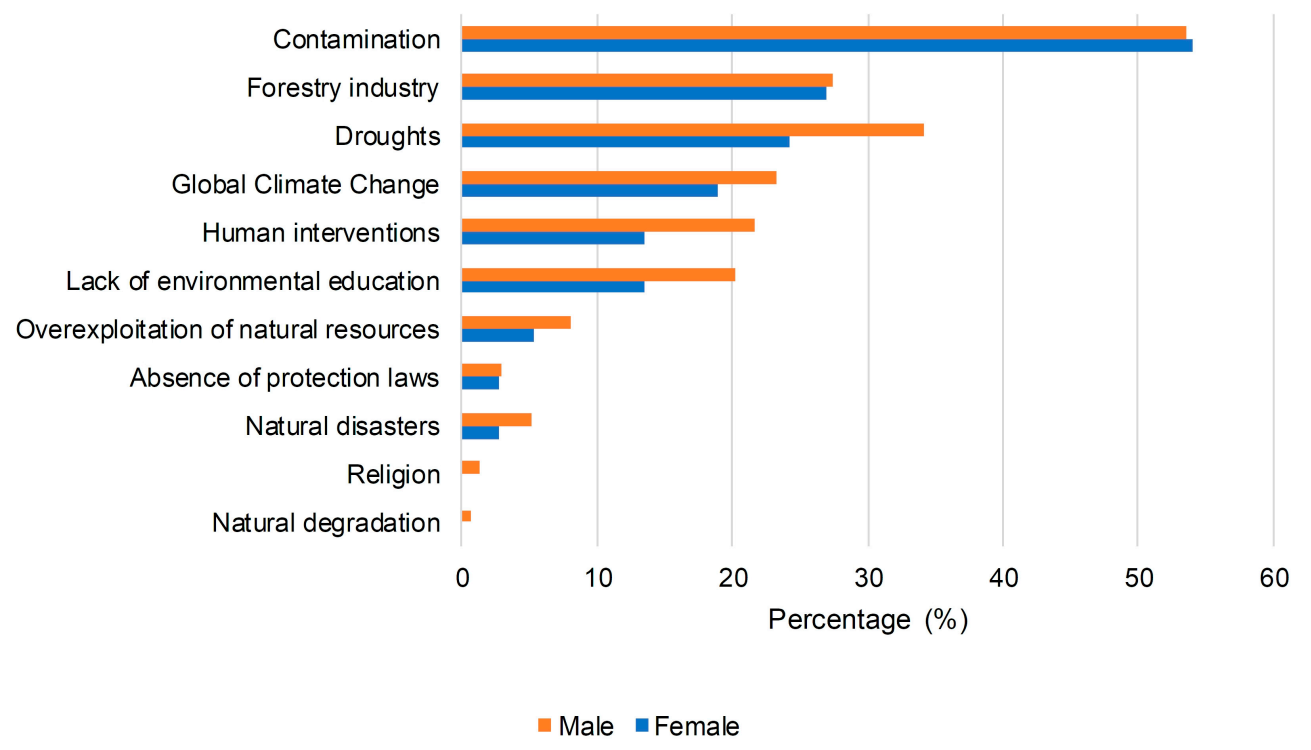

Figure 6. Perception of drivers of change in ecosystem services.

\section{Discussion}

The perceived benefits of ES provision following a large disturbance such as the $2010 M_{\mathrm{W}}=8.8$ earthquake provided a view of the positive valuation of the inhabitants of a Mediterranean salt marsh, which has been declared a Chilean priority site under the National Strategy for Biodiversity Conservation [41]. In general, it was observed that the regulating and cultural ecosystem services obtained a high valuation in terms of frequency of provision despite morphological, social, and environmental changes from the last earthquake. In fact, in the regulating services, the high recurrence of natural (tsunamis, floods) and anthropogenic disasters (fires) that affect the Chilean Mediterranean region [31,37,51] may have positively influenced the utilitarian valuation of the wetland by the population, as it forms part of the inhabitants' collective memory. This is not novel, and is consistent with Barbosa and Villagra [52] as wetlands are essential to mitigate the effects of such catastrophes, and are socially valued as spaces of recovery after earthquakes, especially if they provide biophysical attributes such as water [53].

A similar situation (high social perception) regarding regulating services occurred in the habitat for species service, in the study of Marín et al. [54], carried out 18 months after the earthquake, the diversity of bird species was one of the most important ES perceived by the inhabitants of the Tubul-Raqui fishing village. This perception can be linked to daily observations of the abundant biodiversity provided by the wetland, including local and migratory bird species (83), micromammals (4), reptiles (6), and amphibians (1), which provides a unique sense of landscape beauty. In this regard, the role of collective memory was fundamental. Kunstler (1994), cited by Bouahim et al. [3], recognized the importance of that and the beauty of places in promoting a sense of attachment and human belonging, both key factors in perception studies. Furthermore, Dobbie and Green [4] indicated that intrinsic (habitat, social, esthetic, educational, and tourism) values often dominate the perception of wetlands.

The highlighted result showed that the valuation of cultural services was the highest, with the Tubul-Raqui salt marsh identified as an ecosystem capable of providing opportunities for services related to recreation, local identity, science, and environmental education, as also demonstrated in Australia and the United States [4]. For example, according to Lindborg et al. [55], the positive perception of ES provision is dependent on the connection of people to the landscape, which has been linked to low-intensity primary activities (e.g., agriculture), where habitats maintained in a semi-natural landscape state can offer biological, cultural, and heritage values, a situation similar to that reported in Tubul-Raqui regarding the intensity of economic activities. Regarding science, 
the opportunities for scientific research and environmental education were also highly recognized; the perception of these two services could be related to the large number of studies carried out in the wetland due to the environmental problems that emerged after the 2010 earthquake with various groups of scientists conducting research aimed at assessing the impact and socio-environmental recovery of the system $[33,34,37,39]$ where studies have involved surveying the population and the use of artisanal fishing boats.

Regarding the negative valuation of provisioning services, in the case of water, fuelwood, livestock, and crop development, the results were impressive, especially in water provision, which could have been influenced by the inherent environmental conditions of the system with its low-quality soils and brackish water that do not favor intensive extraction activities or the provision of these services [39]. This situation was in agreement with Bouahim et al. [3], who stated that an increased perception of provision was related to the dependence of the survey respondents on the corresponding ES provision. Algae and fish obtained a greater valuation, even though the official data indicated a significant drop in pelillo extraction, an increase in unemployment, and a decrease in incomes following the 2010 earthquake [37]. Indeed, Marin et al. [54] indicate that navigation and algae services were completely lost after the event. In this study, the greater social perception of the fish and algae production service is explained by three factors. First, this valuation can be explained by the influence of categorical variables, which revealed a greater perception of the service and its benefits by young people, ethnic groups, and people not connected to the primary economic sector, which are also groups that mostly do not engage in extraction activities, a key aspect for making an accurate valuation of the ecosystem service [7], a situation related to the selection procedure of the population inherent to the study.

A second factor is related to the General Fisheries and Aquaculture Law of Chile, which establishes a $5 \%$ increase in extraction quotas following catastrophic events, allowing the extraction of other commercially important species in Tubul to be increased in order to strengthen the local economy (Fisheries and Aquaculture Law Number 20.657, 2013). Finally, despite the substantial physical and environmental disturbances resulting from the tsunami, pelillo extraction exhibited a gradual recovery in 2012, which is supported by recovery of the physical structure of the habitat and the aquatic biota two years after the event in Reference [39]. However, Aswani et al. [14] indicated that social recovery was not always concurrent with environmental recovery, which is undoubtedly related to the perception level of the population; possibly, this environmental recovery will influence the recovery of balance in the exploitation of ES in the Tubul-Raqui wetland, as evidenced by Marín et al. [54].

As previously mentioned, the perceived benefits detected in this study were influenced by the independent categorical variables of gender, age, and ethnicity. However, the main differences were reported regarding gender; for example, the perceived values for hazard regulation services varied strongly, with primarily women recognizing their importance. Possibly, the differences in gender perception may be related to the post-disaster economic effects, which were significantly higher among female gendered persons, who experienced substantial impacts to their labor activities, family incomes and unemployment rate, which reached nearly 31\% [37]. The importance of gender is relevant to perception and has also been recognized in other Mediterranean case studies [3,29]. The differences were smaller in the education and economic sector of the sample, most likely due to the rural and socioeconomic homogeneity of the local population; for example, in the case of education, the percentage of inhabitants with college-level studies was minimal, a situation similar to other fishing villages in Chile [56]. A study of sociocultural valuation done in a nature park in Spain showed that the main characteristics that influenced the valuation were age, place of residence, and education [28]; however, the level of education in that study was higher than that reported in Tubul. Finally, regarding the age variable, we obtained results similar to those of Oteros-Rozas et al. [29], with young people having the highest perception of food-related services and older people having the highest perception of the habitat for species services. 
Finally, the perception of the ES provision 50 years in the future indicated a proportion of stability and a decrease in services; in the drivers of loss, it was observed that the main causes pointed to anthropogenic factors (contamination and the forestry industry), with natural factors ranked second. According to Zorrilla-Miras et al. [12], engines of change are generally interrelated. Indeed, in the Mediterranean region of Chile-specifically in the closer coastal area-increases in production and industrial activities, population, and the level of urbanization have been associated with the loss of surface and biodiversity of these kinds of ecosystems [57-59]. The spread of exotic species such as Pinus radiata is a threat to wetlands as it affects native flora and fauna and causes an alteration in ecosystem functions. Furthermore, it has also been shown that Pinus radiata, with its widespread growth as a monoculture, absorbs a substantial amount of water, therefore decreasing its availability, generating soil changes, and affecting livestock and agricultural activities due to high soil acidity and erosion $[39,42,60]$.

Additionally, natural disasters, as one of the key interests in this study, was the ninth driver of change mentioned by people, despite the scientific community recognizing that the decrease in ES provision (resulting from coseismic uplift of the $M_{\mathrm{W}}=8.8$ earthquake), was linked mainly to the loss of pelillo. Future research could address the phenomena related to the time of personal exposure to these drivers. While pollution and the forestry industry have a more prolonged effect, events such as earthquakes and tsunamis have a shorter duration, making it possible that people with a long history in the location understand that these disturbances occur at certain time intervals and that measures to address them must be developed [13]. This assessment of the perceptions of drivers of loss could be used to manage actions related to conservation, preservation, and the restoration of the system [61] by considering that the opinion of the population is a fundamental element in the current territorial management instruments.

\section{Conclusions}

Salt marshes are sensitive to natural disturbances, as reported following the $2010 M_{W}=8.8$ earthquake-tsunami in Chile. The perception of ES provision after a major disaster was significantly more important in cultural and regulating services; in this sense, residents identified habitat for species, recreation, and hazard regulation as the most important ES. Perception was influenced by the categorical variables of gender, age, and ethnicity; for example, hazard regulation services varied strongly by gender, where the strong post-disaster socioeconomic effects experienced by persons of female gender could be related to their greater perception of this ES. In addition, in the provisioning services category, the fish and algae production were more valued, possibly due to the slight recovery of the activity, but is still at levels that are far below those of the pre-earthquake period (before 2010). In relation to scenarios of ES provision in the next 50 years, the inhabitants of Tubul-Raqui indicate that ES will remain stable (50\%) or decrease (40\%), mainly due to anthropogenic drivers (contamination, the forestry industry); the effect of natural disasters was not mentioned among the main future drivers of change.

Acknowledgments: The FONDECYT (Number 1150459 and Number 11150424) and CONICYT programs of the Chilean government funded this research. We appreciate the information provided by the National Fishing Service (SERNAPESCA in Spanish).

Author Contributions: Octavio Rojas had the original idea for this research and wrote the paper. María Zamorano participated in the data collection and built the database. Katia Saez and Octavio Rojas analyzed the statistical data. Carolina Rojas contributed the survey materials and revised the discussion, conclusions, and to writing the manuscript. Claudio Vega created the maps. Loretto Arrigada analyzed the pelillo data. Corina Busnou revised the methods and the writing of the manuscript. All authors have read and approved the final manuscript.

Conflicts of Interest: The authors declare no conflicts of interest. 


\section{References}

1. Millennium Ecosystem Assessment. Ecosystems and Human Well-Being: Wetlands and Water Synthesis; World Resources Institute: Washington, DC, USA, 2005; ISBN 1569735972.

2. Bertram, C.; Rehdanz, K. Preferences for cultural urban ecosystem services: Comparing attitudes, perception, and use. Ecosyst. Serv. 2015, 12, 187-199. [CrossRef]

3. Bouahim, S.; Rhazi, L.; Ernoul, L.; Mathevet, R.; Amami, B.; Er-riyahi, S.; Muller, S.D.; Grillas, P. Combining vulnerability analysis and perceptions of ecosystem services in sensitive landscapes: A case from western Moroccan temporary wetlands. J. Nat. Conserv. 2015, 27, 1-9. [CrossRef]

4. Dobbie, M.; Green, R. Public perceptions of freshwater wetlands in Victoria, Australia. Landsc. Urban Plan. 2013, 110, 143-154. [CrossRef]

5. Millennium Ecosystem Assessment. Ecosystems and Human Well-Being: Synthesis; Island Press: Washington, DC, USA, 2005; ISBN 1597260401.

6. TEEB (The Economics of Ecosystems and Biodiversity). The Economics of Ecosystems and Biodiversity: Ecological and Economic Foundations; Earthscan: London, UK, 2010.

7. Andersson, E.; Nykvist, B.; Malinga, R.; Jaramillo, F.; Lindborg, R. A social-ecological analysis of ecosystem services in two different farming systems. Ambio 2015, 44, 102-112. [CrossRef] [PubMed]

8. Iniesta-Arandia, I.; García-Llorente, M.; Aguilera, P.A.; Montes, C.; Martín-López, B. Socio-cultural valuation of ecosystem services: uncovering the links between values, drivers of change, and human well-being. Ecol. Econ. 2014, 108, 36-48. [CrossRef]

9. Renaud, F.; Sudmeier-Rieux, K.; Estrella, M. The relevance of ecosystems for disaster risk reduction. In The Role of Ecosystems in Disaster Risk Reduction; Renaud, F., Sudmeier-Rieux, K., Estrella, M., Eds.; United Nations University Press: Tokyo, Japan, 2013; pp. 3-25, ISBN 9789280812213.

10. Ricaurte, L.F.; Olaya-Rodríguez, M.H.; Cepeda-Valencia, J.; Lara, D.; Arroyave-Suárez, J.; Finlayson, C.M.; Palomo, I. Future impacts of drivers of change on wetland ecosystem services in Colombia. Glob. Environ. Chang. 2017, 44, 158-169. [CrossRef]

11. Perennou, C.; Beltrame, C.; Guelmami, A.; Tomas Vives, P.; Caessteker, P. Existing areas and past changes of wetland extent in the Mediterranean Region: An overview. Ecol. Mediterr. 2012, 38, 53-66.

12. Zorrilla-Miras, P.; Palomo, I.; Gómez-Baggethun, E.; Martín-López, B.; Lomas, P.; Montes, C. Effects of land-use change on wetland ecosystem services: A case study in the Doñana marshes (SW Spain). Landsc. Urban Plan. 2014, 122, 160-174. [CrossRef]

13. Losey, R.J. Earthquakes and tsunami as elements of environmental disturbance on the Northwest Coast of North America. J. Anthropol. Archaeol. 2005, 24, 101-116. [CrossRef]

14. Aswani, S.; Putten, I.; Van Miñarro, S. Environmental and social recovery asymmetries to large-scale disturbances in small island communities. Nat. Hazards 2017, 86, 241-262. [CrossRef]

15. Jaramillo, E.; Dugan, J.E.; Hubbard, D.M.; Melnick, D.; Manzano, M.; Duarte, C.; Campos, C.; Sanchez, R. Ecological Implications of Extreme Events: Footprints of the 2010 Earthquake along the Chilean Coast. PLoS ONE 2012, 7, e35348. [CrossRef] [PubMed]

16. Sidle, R.C.; Benson, W.H.; Carriger, J.F.; Kamai, T. Broader perspective on ecosystem sustainability: Consequences for decision making. Proc. Natl. Acad. Sci. USA 2013, 110, 9201-9208. [CrossRef] [PubMed]

17. Cundy, A.B.; Kortekaas, S.; Dewez, T.; Stewart, I.S.; Collins, P.E.F.; Croudace, I.W.; Maroukian, H.; Papanastassiou, D.; Gaki-Papanastassiou, P.; Pavlopoulos, K.; et al. Coastal wetlands as recorders of earthquake subsidence in the Aegean: A case study of the 1894 Gulf of Atalanti earthquakes, central Greece. Mar. Geol. 2000, 170, 3-26. [CrossRef]

18. Fagherazzi, S.; Wiberg, P.L.; Temmerman, S.; Struyf, E.; Zhao, Y.; Raymond, P. Fluxes of water, sediments, and biogeochemical compounds in salt marshes. Ecol. Process. 2013. [CrossRef]

19. Vargas, G.; Farías, M.; Carretier, S.; Tassara, A.; Baize, S.; Melnick, D. Coastal uplift and tsunami effects associated to the $2010 M_{\mathrm{W}} 8.8$ Maule earthquake in Central Chile. Andean Geol. 2011, 38, 219-238.

20. Melnick, D.; Cisternas, M.; Moreno, M.; Norambuena, R. Estimating coseismic coastal uplift with an intertidal mussel: Calibration for the 2010 Maule Chile earthquake $\left(M_{\mathrm{W}}=8.8\right)$. Quat. Sci. Rev. 2012, 42, $29-42$. [CrossRef]

21. Ray, S.K.; Acharyya, A. Coseismic uplift, slow plant mortality and ecological impact in North Andaman following the December $2004\left(M_{\mathrm{W}}>\right.$ 9.2) earthquake. Curr. Sci. 2011, 101, 218-222. 
22. Casado-Arzuaga, I.; Madariaga, I.; Onaindia, M. Perception, demand and user contribution to ecosystem services in the Bilbao Metropolitan Greenbelt. J. Environ. Manag. 2013, 129, 33-43. [CrossRef] [PubMed]

23. Scholte, S.S.K.; van Teeffelen, A.J.A.; Verburg, P.H. Integrating socio-cultural perspectives into ecosystem service valuation: A review of concepts and methods. Ecol. Econ. 2015, 114, 67-78. [CrossRef]

24. Martín-López, B.; Iniesta-Arandia, I.; García-Llorente, M.; Palomo, I.; Casado-Arzuaga, I.; García Del Amo, D.; Gómez-Baggethun, E.; Oteros-Rozas, E.; Palacios-Agundez, I.; Willaarts, B.; et al. Uncovering ecosystem service bundles through social preferences. PLoS ONE 2012. [CrossRef] [PubMed]

25. Kaltenborn, B.P.; Bjerke, T. Associations between environmental value orientations and landscape preferences. Landsc. Urban Plan. 2002, 59, 1-11. [CrossRef]

26. Gos, P.; Lavorel, S. Stakeholders' expectations on ecosystem services affect the assessment of ecosystem service hotspots and their congruence with biodiversity. Int. J. Biodivers. Sci. Ecosyst. Serv. Manag. 2012, 8, 93-106. [CrossRef]

27. Booth, J.E.; Gaston, K.J.; Evans, K.L.; Armsworth, P.R. The value of species rarity in biodiversity recreation: A birdwatching example. Biol. Conserv. 2011, 144, 2728-2732. [CrossRef]

28. Maestre-Andrés, S.; Calvet-Mir, L.; van den Bergh, J.C.J.M. Sociocultural valuation of ecosystem services to improve protected area management: A multi-method approach applied to Catalonia, Spain. Reg. Env. Chang. 2015, 16, 717-731. [CrossRef]

29. Oteros-Rozas, E.; Martín-López, B.; González, J.; Plieninger, T.; López, C.; Montes, C. Socio-cultural valuation of ecosystem services in a transhumance social-ecological network. Reg. Env. Chang. 2014, 14, 1269-1289. [CrossRef]

30. Lomnitz, C. Major earthquakes and tsunamis in Chile during the period 1535 to 1955. Int. J. Earth Sci. 1970, 59, 938-960. [CrossRef]

31. Dura, T.; Cisternas, M.; Horton, B.P.; Ely, L.L.; Nelson, A.R.; Wesson, R.L.; Pilarczyk, J.E. Coastal evidence for Holocene subduction-zone earthquakes and tsunamis in central Chile. Quat. Sci. Rev. 2015, 113, 93-111. [CrossRef]

32. Quezada, J.; Jaque, E.; Férnandez, A.; Vásquez, D. Cambios en el relieve generados como consecuencia del terremoto $M_{\mathrm{W}}=8,8 \mathrm{del} 27$ de febrero de 2010 en el centro-sur de Chile. Rev. Geogr. Norte Gd. 2012, 53, 35-55. [CrossRef]

33. Martínez, C.; Rojas, O.; Jaque, E.; Quezada, J.; Vásquez, D.; Belmonte, A. Efectos territoriales del tsunami del 27 de Febrero de 2010 en la costa de la Región del Bio-Bío. Revista Geográfica de América Central 2011, 2, 1-16.

34. Martínez, C.; Rojas, O.; Aránguiz, R.; Belmonte, A.; Altamirano, A.; Flores, P. Riesgo de tsunami en caleta Tubul, Región del Biobío: Escenarios extremos y transformaciones territoriales posterremoto. Rev. Geogr. Norte Gd. 2012, 53, 85-106. [CrossRef]

35. Farías, M.; Vargas, G.; Tassara, A.; Carretier, S.; Baize, S.; Melnick, D.; Bataille, K. Land-Level Changes Produced by the $M_{\mathrm{W}} 8.82010$ Chilean Earthquake. Science 2010, 329, 916. [CrossRef] [PubMed]

36. Marín, A.; Gelcich, S.; Araya, G.; Olea, G.; Espíndola, M.; Castilla, J. The 2010 tsunami in Chile: Devastation and survival of coastal small-scale fishing communities. Mar. Policy 2010, 34, 1381-1384. [CrossRef]

37. Rojas, O.; Sáez, K.; Martínez, C.; Jaque, E. Post-catastrophe social-environmental effects in vulnerable coastal areas affected by the tsunami of 02/27/2010 in Chile. Interciencia 2014, 39, 383-390.

38. Darwin, C. Geological Observations of South America; Smith, Elder: London, UK, 1851.

39. Valdovinos, C.; Muñoz, M.D.; Sandoval, N.; Vásquez, D.; Viviana, O. Desastres naturales y biodiversidad: El caso del humedal costero Tubul-Raqui. Soc. Hoy 2010, 19, 33-51.

40. Organización de las Naciones Unidas para la Alimentación y la Agricultura (FAO). Arauco: Las Caletas y su Gente; Mohor, S., Ed.; FAO: Arauco, Chile, 2013; p. 192.

41. Centro de Ciencias Ambientales EULA. Guía de Manejo para Terreno Fiscal con Alto Valor en Biodiversidad en la Región del Bio-Bío: Humedal Tubul-Raqui; Centro de Ciencias Ambientales EULA: Concepción, Chile, 2008; p. 143.

42. Valdovinos, C.; Sandoval, N.; Vásquez, D.; Olmos, V. El Humedal Costero Tubul-Raqui: Un ecosistema chileno de alto valor de conservación severamente perturbado por el terremoto 2010. In Humedales Costeros de Chile: Aportes Científicos a su Gestión Sustentable; Fariña, J., Camaño, A., Eds.; Ediciones UC: Santiago, Chile, 2012; pp. 391-437.

43. Constabel, S. Ambientes Sedimentarios de los Estuarios Tubul y Raqui, VIII Región, Chile. Ph.D. Thesis, Universidad de Concepción, Concepción, Chile, 1993. 
44. Instituto Nacional de Estadistica (INE). Censo de Población y Vivienda; INE: Santiago, Chile, 2002.

45. Paul, B.K. Relief assistance to 1998 flood victims: A comparison of the performance of the government and NGOs. Geogr. J. 2003, 169, 75-89. [CrossRef]

46. IBM Corp. IBM SPSS Statistics for Windows, version 24.0; IBM Corp.: Armonk, NY, USA, 2016.

47. Di Rienzo, J.A.; Casanoves, F.; Balzarini, M.G.; Gonzalez, L.; Tablada, M.; Robledo, C.W. InfoStat versión. Available online: http:/ / www.infostat.com.ar/ (accessed on 17 October 2017).

48. Martín, J.F. Los factores definitorios de los grandes grupos de edad de la población: Tipos, subgrupos y umbrales. Scr. Nova 2005, IX. Available online: http://www.ub.es/geocrit/sn/sn-190.htm (accessed on 17 October 2017).

49. Encuesta de Caracterización Socioeconómica Nacional (CASEN). Available online: http:/ / observatorio. ministeriodesarrollosocial.gob.cl/casen/casen_obj.php (accessed on 1 May 2017).

50. Jaramillo, S.; Osses, S. Validación de un Instrumento sobre Metacognición para Estudiantes de Segundo Ciclo de Educación General Básica. Estudios Pedagógicos 2012, XXXVIII, 117-131. [CrossRef]

51. Rojas, O.; Mardones, M.; Rojas, C.; Martínez, C.; Flores, L. Urban Growth and Flood Disasters in the Coastal River Basin of South-Central Chile (1943-2011). Sustainability 2017, 9, 195. [CrossRef]

52. Barbosa, O.; Villagra, P. Socio-Ecological Studies in Urban and Rural Ecosystems in Chile. In Earth Stewardship: Linking Ecology and Ethics in Theory and Praxis; Rozzi, R., Chapin, S.F., Callicott, J.B., Eds.; Springer: Berlin, Germany, 2015; pp. 19-76, ISBN 978-3-319-12133-8.

53. Villagra, P.; Rojas, C.; Ohno, R.; Xue, M.; Gómez, K. A GIS-base exploration of the relationships between open space systems and urban form for the adaptive capacity of cities after an earthquake: The cases of two Chilean cities. Appl. Geogr. 2014, 48, 64-78. [CrossRef]

54. Marín, A.; Gelcich, S.; Castilla, J.C. Ecosystem Services and Abrupt Transformations in a Coastal Wetland Social-Ecological System: Tubul-Raqui after the 2010 Earthquake in Chile. Ecol. Soc. 2014, 19, 22. [CrossRef]

55. Lindborg, R.; Bengtsson, J.; Berg, A.; Cousins, S.A.O.; Eriksson, O.; Gustafsson, T.; Hasund, K.P.; Lenoir, L.; Pihlgren, A.; Sjödin, E.; et al. A landscape perspective on conservation of semi-natural grasslands. Agric. Ecosyst. Environ. 2008, 125, 213-222. [CrossRef]

56. La Pesca Artesanal en Caleta Horcon. Available online: http://www.caletahorcon.cl/reportajes/ PescaArtesanal.htm (accessed on 15 May 2017).

57. Pauchard, A.; Aguayo, M.; Peña, E.; Urrutia, R. Multiple effects of urbanization on the biodiversity of developing countries: The case of a fast-growing metropolitan area (Concepcion, Chile). Biol. Conserv. 2006, 127, 272-281. [CrossRef]

58. Rojas, C.; Sepúlveda-Zúñiga, E.; Barbosa, O.; Rojas, O.; Martínez, C. Patrones de urbanización en la biodiversidad de humedales urbanos en Concepción metropolitano. Rev. Geogr. Norte Gd. 2015, 61, 181-204. [CrossRef]

59. Smith, P.; Romero, H. Efectos del Crecimiento Urbano del Área Metropolitana de Concepcion Sobre los Humedales de Rocuant-Andalien, Los Batros y Lenga. Rev. Geogr. Norte Gd. 2009, 43, 81-93. [CrossRef]

60. Sistema Nacional de Información Ambiental (SINIA). Capítulo V: El Mundo Rural: Novena Región de la Araucanía; Comisión Nacioanal del Medio Ambiente (CONAMA): Santiago, Chile, 2013.

61. Felipe-Lucia, R.; Comín, F.A.; Escalera-Reyes, J. A framework for the social valuation of ecosystem services. Ambio 2015, 44, 308-3181. [CrossRef] [PubMed]

(c) 2017 by the authors. Licensee MDPI, Basel, Switzerland. This article is an open access article distributed under the terms and conditions of the Creative Commons Attribution (CC BY) license (http://creativecommons.org/licenses/by/4.0/). 